\title{
TELUK CENGAL : LOKASI PELABUHAN SRIWIJAYA?
}

\section{BAY OF CENGAL : THE LOCATION OF SRIVIJA YA PORT?}

\author{
Nurhadi Rangkuti \\ Balai Arkeologi DI Yogyakarta \\ nurhadirangkuti@gmail.com
}

\begin{abstract}
Archaeological researches in southeast coast of Sumatra find archaeological prove of Srivijaya era (7-13 AD). Settlement sites located along tidal swamp rivers near shoreline. Srivijaya communities lived on house on stilts from wood on the wetlands. The artifacts came from aboard, eg. Chinese ceramics, beads from India and glasses from Persian found with local artifacts. Also found boats of Southeast Asia tradition use sewn plank and lashed-lug technique. These artifacts represent maritime activities in southeast coast of Sumatra. Estimated southeast coast of Sumatra, which facing Strait of Bangka, is an archaeological settlement area of Srivijaya and also pre Srivijaya periods. This one have the harbour and the port. This paper tried to identify one of the archaeological settlement area which estimated as an entreport of Srivijaya period. This area located in Bay of Cengal, District of Ogan Komering Ilir, Province of South Sumatra. Remains of activity area concentrated in Lumpur River basin and empties into Java Sea. Identification an archaeological settlement area in Bay of Cengal based on archeological data analysis, textual and maps resources, environment and position of Bay of Cengal in global maritime networks of Srivijaya
\end{abstract}

Keywords: Bay of Cengal, Srivijaya, boats of Southeas Asia tradition, entreport.

\begin{abstract}
ABSRTAK
Penelitian arkeologi di pesisir tenggara Sumatra menemukan bukti-bukti arkeologis yang sezaman dengan berkembangnya Sriwijaya di Sumatra (7-13 M). Situs-situs hunian mengelompok di tepi aliran sungai rawa pasang surut. Situs-situs tersebut berada di hilir sungai yang lokasinya relatif dekat dengan garis pantai sekarang. Penduduk masa Sriwijaya tinggal pada rumah-rumah panggung bertiang kayu di lahan basah. Artefak-artefak yang ditemukan sebagian besar berasal dari luar negeri, seperti keramik Cina, manik-manik dari India dan kaca-kaca dari Persia dijumpai bersama dengan barang-barang lokal, seperti barang-barang dari tembikar. Ditemukan pula perahu-perahu kuna tipe Asia Tenggara berupa perahu kayu yang dibuat dengan teknik papan ikat (sewn plank) dengan menggunakan tali ijuk dan juga menggunakan pasak kayu. Bukti-bukti arkeologis tersebut menunjukan adanya aktivitas kemaritiman di pantai tenggara Sumatra. Diperkirakan pantai tenggara Sumatra yang berhadapan dengan Selat Bangka dan Laut Jawa merupakan kawasan okupasi masa Sriwijaya dan masa sebelumnya yang dilengkapi bandar pelabuhan. Tulisan ini berupaya mengidentifikasi salah satu kawasan situs di pantai tenggara Sumatra yang diperkirakan sebagai permukiman dan bandar pelabuhan masa Sriwijaya. Kawasan itu berada di Teluk Cengal yang terdapat di pantai timur Kabupaten Ogan Komering Ilir, Provinsi Sumatera Selatan. Tinggalan arkeologis terkosentrasi di daerah aliran Sungai Lumpur yang bermuara di Laut Jawa. Upaya mengidentifikasi kawasan situs di Teluk Cengal dilakukan berdasarkan analisis data arkeologi, sumber tertulis dan peta, keadaan lingkungan dan posisi Teluk Cengal dalam jaringan pelayaran maritim global masa Sriwijaya.
\end{abstract}

Kata kunci: Teluk Cengal, Sriwijaya, perahu Tradisi Asia Tenggara, pelabuhan antara.

Tanggal Masuk : :03 Agustus 2017

Tanggal Diterima : 27 September 2017 


\section{PENDAHULUAN}

Pesisir tenggara Sumatra (Provinsi Jambi dan Provinsi Sumatera Selatan) kaya dengan bukti-bukti arkeologis masa Sriwijaya di Sumatra (abad ke-7-13 M). Hal yang menarik di lahan basah pesisir tersebut terdapat situs-situs arkeologi pra Sriwijaya atau dikenal dengan istilah situs praSriwijaya. Hal ini membuktikan bahwa lahan basah pesisir tenggara Sumatra telah menjadi daerah bermukim setidaktidaknya sejak awal tarikh Masehi berdasarkan analisis pertanggalan pada berbagai jenis artefak. Situssitus hunian mengelompok di tepi aliran sungai rawa pasang surut. Situs-situs tersebut berada di hilir sungai yang lokasinya agak ke dalam dari garis pantai sekarang. Rupa-rupanya penduduk zaman kuna tinggal pada rumah-rumah panggung bertiang kayu dari batang nibung dan batang kayu keras. Sejumlah barang rumah tangga berasal dari luar negeri, seperti keramik Cina, tembikar Arikamedu, India, manik-manik dan kaca-kaca dari Persia dijumpai bersama dengan barang-barang lokal, antara lain wadah-wadah gerabah. Pada beberapa situs permukiman ditemukan perahu-perahu kayu yang dibuat dengan teknik papan ikat dengan menggunakan tali ijuk dan juga pasak kayu. Ditemukannya sejumlah perahu kuna dalam kondisi fragmentaris menggambarkan sarana transportasi masyarakat kuna pada lahan basah di pesisir tenggara Sumatra.

Sampai sekarang belum dapat diidentifikasi secara pasti bentuk dan tata ruang situs bandar pelabuhan Sriwijaya di pesisir tenggara Sumatra. Diperkirakan bandar pelabuhan masa Sriwijaya dan masa sebelumnya berada pada tepian sungai yang relatif dekat dengan garis pantai teluk yang terlindung dari gelombang laut. Sarana dan prasarana bandar pelabuhan pada zaman dahulu tidaklah selengkap zaman sekarang. Disebut pelabuhan bisa hanya berupa tiang penambat perahu dan dermaga kayu yang sederhana di tepi sungai. Ekskavasi di Situs Kota Kapur, di Pulau Bangka, menemukan sisa-sisa dermaga di tepi Sungai Mendo. Sisa-sisa dermaga itu berupa susunan kayu dan tiang-tiang kayu yang berdiri tegak. Kayu yang digunakan dari nibung dan pelangis (Utomo, 2015:126). Arkeolog belum menemukan tempat bongkar muat barang, gudang-gudang dan pabean yang lazim terdapat pada bandar pelabuhan.

Pantai tenggara Sumatra memiliki beberapa teluk dan tanjung yang menghadap ke Selat Bangka. Selat ini menjadi tempat bermuara sungai-sungai besar. Sungai-sungai yang bermuara, dari barat ke timur, yaitu Sungai Banyuasin, Sungai Musi (Sungsang), Sungai Saleh, dan Air Sugihan. Selain itu Selat Bangka juga menjadi tempat bermuara sungai-sungai lain yang sumbernya dari rawa-rawa pasang surut sekitar pantai. Penelitian arkeologi di pantai tenggara Sumatra di Provinsi Sumatra Selatan telah dilakukan di Air Sugihan dan Karangagung Tengah (bagian dari DAS Banyuasin) oleh Pusat Penelitian Arkeologi Nasional dan Balai Arkeologi Provinsi Sumatera Selatan (Balar Sumsel) sejak tahun 1980 awal sampai sekarang. Hasil penelitian memberikan gambaran mengenai permukiman kuna sejak awal tarikh Masehi sampai berkembangnya Sriwijaya di Sumatra abad ke-7-13 Masehi di Air Sugihan. Sementara itu okupasi di Situs Karangagung Tengah (di 
Kabupaten Musi Banyuasin) sampai abad ke-4-5 Masehi.

$$
\text { Makalah ini berupaya }
$$

mengidentifikasi satu kawasan situs di pantai tenggara Sumatra yang diperkirakan sebagai bandar pelabuhan masa Sriwijaya. Kawasan itu berada di Teluk Cengal di Kabupaten Ogan Komering Ilir, Provinsi Sumatera Selatan. Tepatnya di wilayah Kecamatan Cengal dan Kecamatan Tulung Selapan. Di wilayah tersebut terdapat situs-situs arkeologi. Salah satu lokasi situs yang penting untuk dikaji lebih lanjut adalah situs-situs yang terdapat di Desa Ulak Kedondong dan sekitarnya di daerah aliran Sungai Lumpur di Kecamatan Cengal. Kawasan situs itu menjadi perhatian para arkeolog ketika terjadi kebakaran hutan dan lahan pada akhir tahun 2015. Kebakaran menghanguskan hutan tanaman industri ( $\mathrm{HTI})$ pohon akasia dan rawa gambut di wilayah PT Bumi Mekar Hijau (BMH) di wilayah Desa Ulak Kedondong dan sekitarnya di Kecamatan Cengal. Kebakaran juga menghanguskan tinggalan arkeologis yang terdapat di permukaan dan di bawah permukaan tanah. Peninjauan yang dilakukan pada awal tahun 2016 oleh tim Balai Arkeologi Sumatera Selatan di lokasi menjumpai kondisi situs yang telah rusak karena kebakaran dan aktivitas penggalian liar oleh kelompok-kelompok orang untuk mengambil artefak-artefak emas, keramik, manik-manik dan bahkan tiang-tiang kayu bangunan kuna yang dianggap bernilai ekonomi. Kawasan ini mencakup wilayah yang luas, di antara Sungai Langipi dan Sungai Ketupak, yang keduanya bertemu dengan Sungai Lumpur.

Kawasan situs Ulak Kedondong dan sekitarnya yang luas dan padat dengan tinggalan arkeologis perlu ditelaah lebih lanjut mengenai karakter situs dan fungsinya dengan mempertimbangkan lokasinya di pantai timur Provinsi Sumatera Selatan yang menghadap ke Laut Jawa dan Selat Bangka Perairan tersebut merupakan jalur pelayaran yang ramai pada masa Sriwijaya. Apakah kawasan situs di Teluk Cengal pernah menjadi bandar pelabuhan pada masa Sriwijaya?

Pertanyaan penelitian tersebut dilandasi oleh kerangka teori bahwa Sriwijaya merupakan kerajaan yang berkembang karena terlibat dan punya peran penting dalam jaringan perdagangan global maritim antara Asia dan Asia Tenggara sejak milenium pertama. Perdagangan maritim pada masa lalu mengikuti pergantian musim, yaitu adanya keteraturan angin di Asia tropis. Dari April sampai Agustus angin musim bertiup ke utara menuju daratan Asia; dari Desember sampai Maret angin dipastikan bertiup ke selatan, dari daratan Asia ke Samudra India dan Laut Cina Selatan (Reid 2015:77). Keteraturan angin musim itu menentukan pola perdagangan maritim Asia. Menurut Reid pelayaran berdasarkan musim ini berakibat berkembangnya pelabuhan antara (entreport) di Asia Tenggara dimana para pedagang dapat menunggu pergantian musim atau kedatangan rekan dagangnya. Pelabuhan antara di kawasan bawah angin (Asia Tenggara) memilih tempat di persimpangan persinggahan pelayaran berdasarkan musim ini yaitu di perairan yang terlindung (ibid,78).

Sriwijaya yang menguasai jalur perdagangan maritim di Selat Malaka dan Selat Bangka, tentunya memiliki pelabuhan antara di sepanjang pantai perairan tersebut. 
Berkenaan dengan bandar pelabuhan di Selat Bangka, arkeolog terus mencari situs bandar pelabuhan di pesisir Bangka dan pesisir Sumatera Selatan. Di Situs Kota Kapur di pesisir Bangka, tim Pusat Penelitian Arkeologi Nasional telah berhasil menemukan sisa-sisa dermaga kayu (Utomo, 2015:111127). Sementara itu pencarian situs bandar pelabuhan di pesisir Sumatera Selatan terus menerus dilakukan di kawasan Air Sugihan, baik di Air Sugihan Kiri (Kabupaten Banyuasin) maupun Air Sugihan Kanan (Kabupaten Ogan Komering Ilir). Pada kedua kawasan tersebut telah ditemukan perahu-perahu kuna, namun arkeolog belum berhasil menemukan sisa-sisa bandar pelabuhan kuna seperti bangunan dermaga kayu yang menguatkan bukti adanya bandar pelabuhan.

Dari berbagai indikasi adanya bandar pelabuhan kuna di pesisir tenggara Sumatra, kawasan Teluk Cengal memiliki potensi yang besar sebagai lokasi pelabuhan antara, ditinjau dari posisi kawasan itu yang berada di persimpangan jalur maritim antara Selat Bangka, Laut Jawa dan Selat Sunda. Survei arkeologi telah dilakukan pada tahun 1992 di wilayah Teluk Cengal dan dilanjutkan pada tahun 2012 dan 2015 oleh tim Balai Arkeologi Sumatera Selatan. Pada akhir tahun 2015 terjadi kebakaran lahan di Cengal yang berakibat terungkapnya tinggalan arkeologis di wilayah Desa Ulak Kedondong, Kecamatan Cengal, Kabupaten Ogan Komering Ilir. Penggalian liar dilakukan secara besar-besaran menemukan berbagai jenis artefak, sisa-sisa bangunan kayu dan kepingan-kepingan papan perahu kuna dalam satu area yang luas.

\section{METODE}

Pendekatan arkeologi lanskap (landscape archaeology) digunakan untuk mengetahui posisi Teluk Cengal dalam jaringan maritim masa Sriwijaya di Asia Tenggara. Dalam hal ini Teluk Cengal merupakan bagian dalam lanskap maritim Sriwijaya yang menguasai bandar pelabuhan di daerah pantai Selat Malaka, Selat Bangka dan Laut Jawa. Teluk Cengal dianggap memiliki lokasi yang strategis, yaitu berada pada jalur yang menghubungkan ketiga wilayah tersebut. Posisi tersebut berpengaruh terhadap perkembangan permukiman di Teluk Cengal.

Data yang digunakan dalam kajian ini meliputi data arkeologi, data tertulis dan piktorial (peta). Data arkeologi yang dianalisis meliputi jenis-jenis temuan (situs, artefak, ekofak dan feature) bentuk dan tipe temuan, dan pertanggalan (dating) dan asal temuan. Sebagian besar tinggalan arkelogis yang dikaji diperoleh masyarakat dengan cara penggalian liar sehingga telah menghilangkan informasi tentang matriks, asosiasi dan konteks tinggalan arkeologis. Oleh karena itu kajian ini merupakan kajian awal untuk memberikan indikasi adanya bandar pelabuhan di Teluk Cengal.

Berkaitan dengan kondisi data tersebut, dilakukan telaah keruangan (spatial analysis) dalam skala makro. Dalam hal ini Teluk Cengal adalah satu wilayah aktivitas masyarakat masa lalu (Sriwijaya) yang memiliki pola permukiman tertentu. Pola permukiman dipengaruhi oleh kondisi lingkungan setempat. Dalam analisis spasial tersebut diamati persebaran dan hubungan antarsitus dan lingkungannya di wilayah Teluk Cengal. Analisis tersebut digunakan untuk menafsirkan adanya bandar 
pelabuhan dalam kawasan permukiman di Teluk Cengal pada masa Sriwijaya.

\section{HASIL PENELITIAN}

\section{Teluk Cengal}

Pantai timur Provinsi Sumatera Selatan berada di wilayah Kabupaten Ogan Komering Ilir (OKI).

(Kecamatan Tulungselapan) di bagian utara dan Tanjung Menjangan di bagian selatan (Kecamatan Sungai Menang) yang berbatasan dengan Provinsi Lampung.

Teluk ini berhadapan dengan pertemuan perairan Selat Bangka dan Laut Jawa. Tanjung Kait berhadapan dengan Pulau Maspari dengan jarak sekitar $14 \mathrm{~km}$. Pulau ini

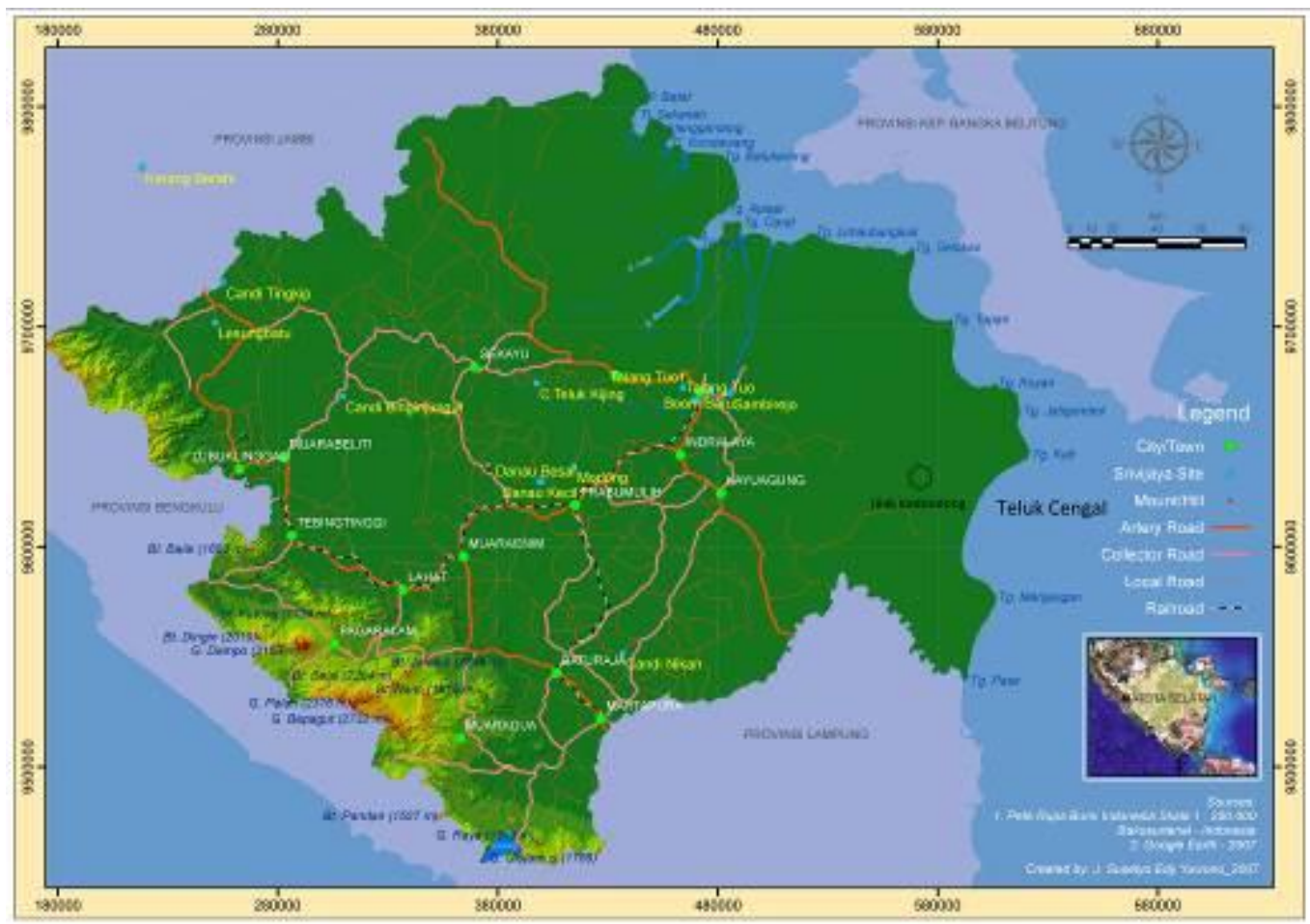

Gambar 1. Peta Teluk Cengal di pantai timur Sumatera Selatan

(Sumber: dok. Balar Sumsel 2007 dengan penambahan keterangan lokasi Teluk Cengal)

Pantai ini memiliki tanjung-tanjung dan ceruk-ceruk yang terletak di wilayah Kecamatan Tulung Selapan, Kecamatan Cengal dan Kecamatan Sungai Menang. Teluk Cengal yang dimaksud dalam kajian ini adalah suatu ceruk pantai yang paling lebar di pantai timur Kabupaten OKI meliputi wilayah tiga kecamatan, yaitu dari utara ke selatan Kecamatan Tulung Selapan, Kecamatan Cengal dan Kecamatan Sungai Menang. Teluk Cengal diapit oleh dua tanjung, yaitu Tanjung Kait dikenal juga dengan nama Lucipara oleh para pelaut.

Sebagian besar wilayah Teluk Cengal merupakan daerah lahan basah berupa tanah gambut. Lahan basah tersebut berasal dari endapan rawa dengan material bahan organik (gambut), pasir halus dan lempung. Di antara lahan basah terdapat tanah mineral yang kering berasal dari Formasi Muara Enim yang terdiri atas batupasir kuarsa berseling dengan batupasir. Tanah mineral terhampar di bagian selatan 
Teluk Cengal, yang dikelilingi tanah gambut (peta Mangga et al, 1993).

Teluk Cengal menjadi tempat bermuara sungai-sungai pasang surut yang berpola dendritik, antara lain Sungai Pidada, Sungai Riding dan Sungai Lebung Hitam (Kecamatan Tulung Selapan), Sungai Lumpur, Sungai Jeruju dan Sungai Pasir (Kecamatan Cengal). Sungai Lumpur merupakan sungai terbesar di Teluk Cengal. Sungai ini sebagai batas wilayah Kecamatan Tulungselapan dan wilayah Kecamatan Cengal. Sungai Lumpur memiliki cabang sungai, antara lain Sungai Langipi, Sungai Ketupak, Sungai Kemang, Sungai Belidang dan Sungai Tangkallesso.

Jika ditarik garis lurus, Teluk Cengal terletak di sebelah tenggara Kota Palembang dengan jarak sekitar $135 \mathrm{~km}$. Tidak ada jaringan sungai yang menghubungkan Teluk Cengal dengan Kota Palembang. Untuk mencapai pantai Teluk Cengal dari Kota Palembang dapat ditempuh melalui jalan darat dan dilanjutkan dengan menyusuri garis pantai dan Sungai Lumpur dengan perahu.

Data arkeologi yang diperoleh melalui penelitian dan temuan penduduk di pesisir tenggara Sumatra (Jambi dan Sumatera Selatan) terdapat di sekitar aliran sungai rawa pasang surut. Di daerah lahan basah tersebut banyak ditemukan sisa-sisa perahu kuna, sisa-sisa bangunan panggung bertiang kayu dan artefak-artefak impor dari Cina, India dan Persia. Data arkeologis tersebut menyiratkan aktivitas masyarakat masa lalu yang tinggal mengelompok di tepi sungai yang menggunakan perahu sebagai alat transportasi di sungai dan laut. Kelompok-kelompok masyarakat tersebut telah mengenal hubungan perdagangan internasional dengan ditemukannya artefak-artefak impor di kawasan permukiman mereka.

\section{Perahu Tradisi Asia Tenggara}

Jenis perahu yang sering ditemukan di pesisir tenggara Sumatra (Sumatera Selatan dan Jambi) adalah perahu yang dikenal dengan istilah perahu tradisi Asia Tenggara. Perahu dibuat dengan teknik papan ikat dan teknik pasak kayu (lash lug and stitched plank technique) dan teknik gabungan keduanya (Koestoro, 1993:C1-6- C17) . Di pesisir tenggara Sumatra jenis perahu Asia Tenggara ditemukan di Lambur (Jambi), Mulyaagung di Karangagung Tengah (2012), Margomulo di Air Sugihan (2010), Sungai Buah dan Sambirejo (Palembang). Jenis perahu tersebut juga ditemukan papan-papannya di Situs Kota Kapur (Pulau Bangka) yang letaknya di pesisir Selat Bangka (Rangkuti 2007:48).

Di wilayah Teluk Cengal, fragmen-fragmen perahu kuna tradisi Asia Tenggara ditemukan pertama kali pada tahun 1992 di Desa Tulung Selapan, Kecamatan Tulung Selapan. Sisa-sisa perahu yang ditemukan antara lain tali ijuk (arenga pinnata) sebagai pengikat papan perahu (sewn plank), pasak kayu dan papan-papan perahu (Wiyana, 2013:149-154). Temuan berikutnya pada tahun 2009 ketika seorang penduduk Desa Pasir, Kecamatan Cengal menemukan perahu kuna di dalam Sungai Pasir. Bangkai perahu kayu itu kemudian diangkat dalam kondisi yang relatif lengkap mulai dari bagian haluan sampai buritan. Tim Balai Arkeologi Sumatera Selatan meninjau temuan tersebut pada 2012. Dijumpai papan-papan perahu terserak di tanah dan sebagian papan-papan 
perahu dijadikan jerambah (jembatan) untuk menghubungkan rumah-rumah penduduk yang berupa rumah panggung dari kayu. Artefak-artefak yang ditemukan dalam perahu adalah fragmenfragmen keramik-keramik dan tembikar yang sebagian besar telah pecah, artefak-artefak kayu dan tempurung-tempurung kelapa. Artefak kayu berupa sendok kayu (centong) berukuran panjang $21 \mathrm{~cm}$ dan kayu panjang membulat seperti alu (antan) berukuran $136 \mathrm{~cm}$. Diperkirakan sendok kayu dan tempurung kelapa digunakan sebagai peralatan makan-minum di kapal. Tempurung-tempurung kelapa juga ditemukan pada kapal tradisi Asia Tenggara abad ke-7 di Punjulharjo, Rembang Jawa Tengah (Abbas 2013:63). Kayu bulat panjang berbentuk alu belum diketahui secara pasti fungsinya.

Tercatat ada 17 keping perahu yang terdiri dari bagian lunas (dua fragmen, satu lunas utuh) dan 14 papan perahu yang terdiri dari bagian badan dan bagian buritan untuk menempatkan kemudi. Menurut informasi penduduk ditemukan juga bagian kepala depan perahu yang berbentuk dua pedang, namun sekarang telah hilang. Panjang lunas yang utuh adalah 14,53 meter. Sebagian besar papanpapan yang ditemukan tahun 2009, telah patah. Papan yang paling panjang berukuran 9,5 meter dan ketebalan papan-papan antara $3,5 \mathrm{~cm}-4 \mathrm{~cm}$. Papan-papan perahu itu memiliki tonjolan berbentuk segi empat, disebut tambuku. Pada bagian tambuku dan bagian tebal papan terdapat lubang-lubang kecil untuk memasukan tali ijuk untuk menyambung antarpapan perahu.

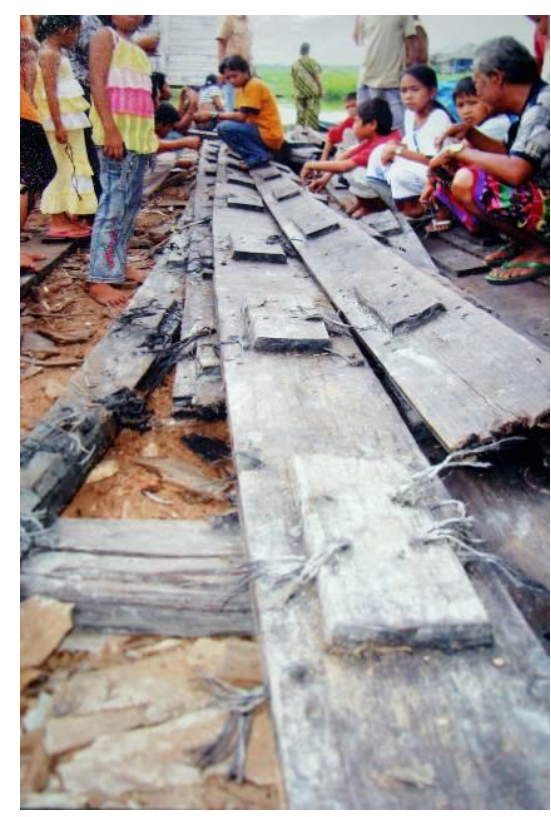

Gambar 2. Papan perahu dengan tambuku setelah diangkat dari dasar sungai (Sumber: dok. Desa Pasir 2009)

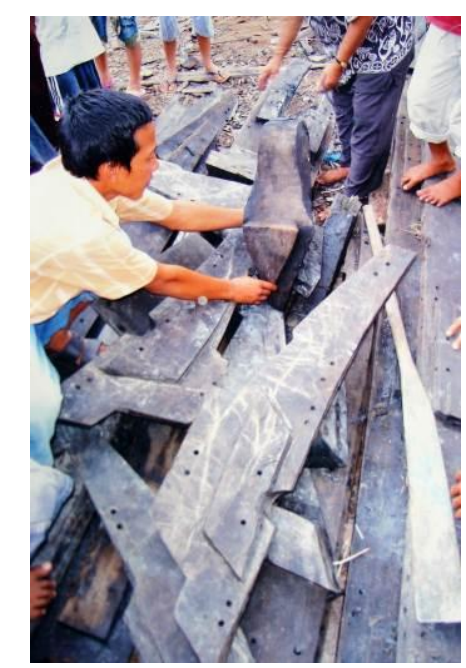

Gambar 3. Bagian haluan perahu

(Sumber: dok. Desa Pasir 2009)

Pada tahun 2015 tim Balar Sumsel mendata temuan sekeping papan perahu di Desa Simpang Tiga Sakti (sebelumnya disebut Desa Buntuan), Kecamatan Tulung Selapan. Lokasi berada di sekitar aliran Sungai Bekasi bagian dari Sungai Lebunggajah. Panjang perahu di Sungai Bekasi sekitar 21$25 \mathrm{~m}$. Sekitar 300 meter dari lokasi 
perahu ditemukan sisa-siang tiang bangunan kayu dari batang nibung. Bagian perahu yang masih tersisa di lokasi adalah satu keping papan dengan ukuran panjang $357 \mathrm{~cm}$, lebar $29 \mathrm{~cm}$, dan tebal $5 \mathrm{~cm}$. Pada papan tersebut terdapat lima buah tonjolan tambuku, tiga buah masih utuh dan dua buah sudah rusak. Masing-masing tambuku mempunyai ukuran sama, panjang $32 \mathrm{~cm}$, lebar $20 \mathrm{~cm}$, dan tebal $2 \mathrm{~cm}$. Jarak antar tambuku $50 \mathrm{~cm}$. Lubang-lubang pasak dan tali ijuk semuanya telah rusak. Diameter lubang pasak dan tali ijuk $4 \mathrm{~cm}$. Sebagian papan perahu ini terbakar akibat kebakaran lahan pada saat kemarau panjang (Wiyana et al, 2015).

Tim arkeologi juga melakukan pencarian perahu kuna Di Desa Ulak Kedondong. Temuan perahu kuna berada di lokasi yang disebut Talang Sekuncit, Dusun 1 Desa Ulak Kedondong (Wiyana et al, 2015) .
Tim menemukan lima buah papan perahu kuna yang terbakar akibat kebakaran lahan gambut. Panjang papan-papan yang tersisa antara $85 \mathrm{~cm}-145 \mathrm{~cm}$, lebar $18-22$ $\mathrm{cm}$ dan tebal papan-papan antara 2,8 - $3 \mathrm{~cm}$. Pada papan-papan tersebut terdapat tambuku dengan ukuran yang berbeda, yaitu (1) panjang $45 \mathrm{~cm}$, lebar $12 \mathrm{~cm}$, tebal $0,5 \mathrm{~cm}$. (2) panjang $41 \mathrm{~cm}$, lebar 14 $\mathrm{cm}$, tebal $1,0 \mathrm{~cm} \mathrm{(3)}$ panjang 43,5 $\mathrm{cm}$, lebar $22,5 \mathrm{~cm}$, dan tebal $1,0 \mathrm{~cm}$.

\section{Kawasan Situs di Desa Ulak Kedondong dan Sekitarnya}

Kawasan situs Ulak Kedondong merupakan bagian dari Daerah Aliran Sungai Lumpur di wilayah Kecamatan Cengal, Kabupaten OKI. Situs-situs arkeologi terdapat pada aliran Sungai Langipi dan Sungai Ketupak (Rangkuti dan Wiyana, 2016). Kawasan Situs di aliran Ketupak-Langpipi sebagian

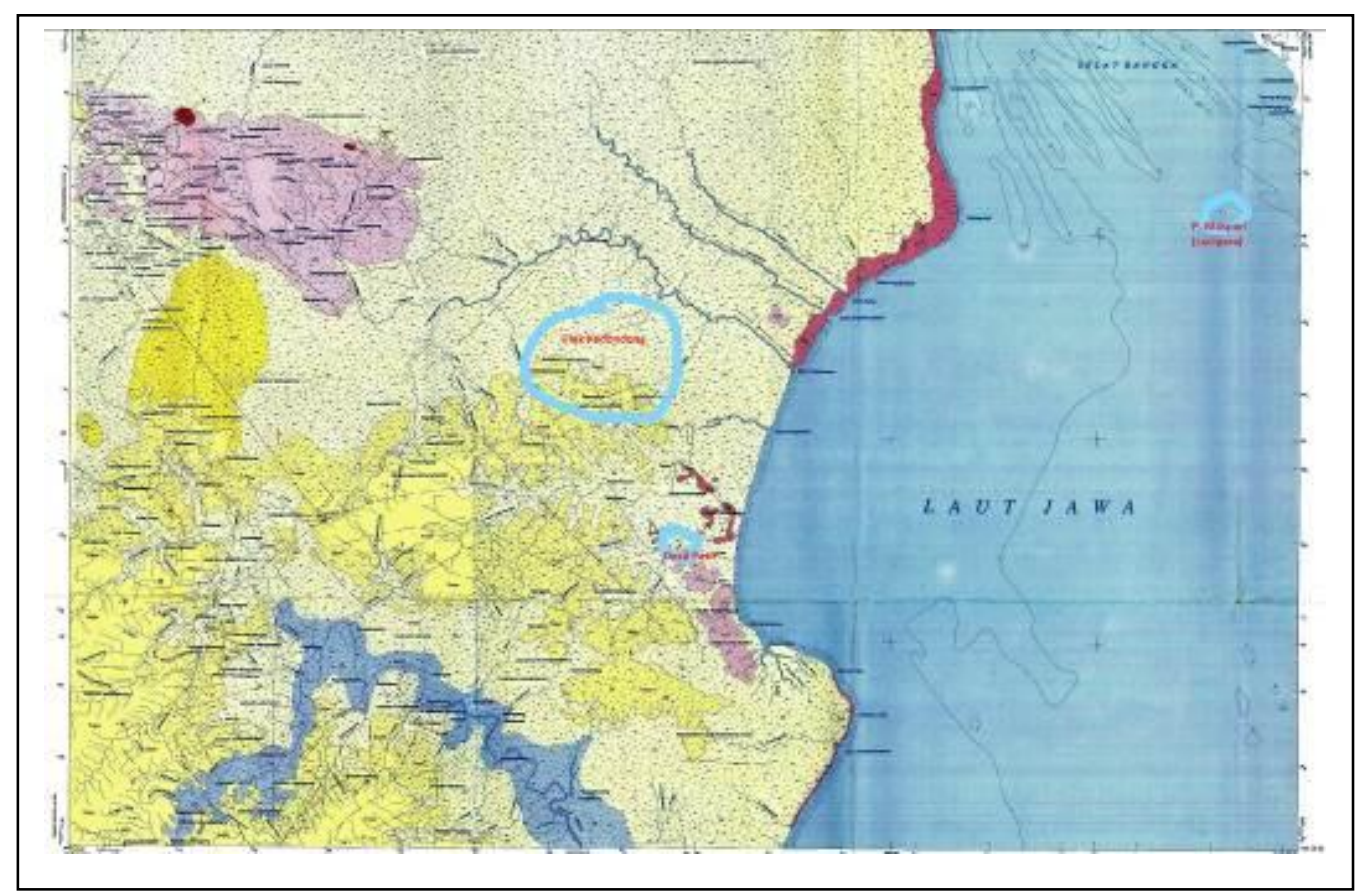

Gambar 4. Lokasi Kawasan Ulak Kedondong, Desa Pasir dan Pulau Maspari (Sumber: Peta Geologi Lembar Tulung Selapan 1993 dengan penambahan). besar wilayahnya berada di konsesi Hutan Tanaman Industri (HTI) yang dikelola oleh PT Bumi Mekar Hijau. 
Sebagian situs berada pada hamparan tanah mineral di antara tanah gambut. Pasca kebakaran lahan gambut tahun 2015, Tim Balai Arkeologi Sumatera Selatan mengadakan peninjauan ke lokasilokasi situs di wilayah Desa Ulak Kedondong dan sekitarnya dipandu penduduk setempat.

Tim mengunjungi lokasi kebakaran tahun 2015 di kawasan Hutan Tanaman Industri (HTI) di Distrik Sungai Ketupak (41.067,56 ha). Situs- situs yang terbakar terdapat pada tempat-tempat yang bernama Bukit Tengkorak, Pulau Pisang dan Kanal 12. Tim tiba di Kanal 12 setelah menelusuri kanalkanal buatan dengan perahu bermotor.

Lahan gambut di Kanal 12 seluas 50 ha itu tergenang air saat musim hujan. Gundukan-gundukan tanah bekas galian pencari harta karun menyembul di antara genangan air. Tim Arkeologi mengais gundukan-gundukan yang telah ditinggal para penggali harta karun. Mereka meninggalkan pecahan-pecahan tembikar dan keramik kuna, fragmen-fragmen kaca impor, kepingan papan perahu kuna dan beberapa butir manikmanik kuna.

Kebakaran lahan tahun 2015 telah menghanguskan semak-semak yang tinggi di tempat itu. Bara api sampai ke bawah permukaan tanah sedalam 1-2 meter. Para penggali harta karun banyak menemukan guci-guci keramik dan tiang-tiang kayu kuna ikut hangus terbakar. Menurut informasi penduduk yang terlibat penggalian liar, ribuan tiang kayu kuno dan artefak-artefak lainnya ditemukan di Kanal 12, Pulau Pisang, Bukit Tengkorak, sampai ke wilayah Desa Jeruju (Rangkuti, 2016 mangobay.co.id). Di
Situs Kanal 12 juga ditemukan batu prasasti pendek oleh penduduk.

Saat survei di Kanal 12 tim menemukan pecahan-pecahan artefak kaca warna hijau transparan dan kuning transparan tetapi tidak diketahui bentuk utuhnya. Bendabenda dari kaca semacam itu terdapat pula pada barang muatan kapal tenggelam dari abad ke-10 di perairan utara Jawa di Cirebon bagian utara, Jawa Barat. Barangbarang kaca yang berjumlah lebih dari 3000 buah itu diperkirakan berasal dari Persia, meliputi bentuk botol, karaf (botol minuman sejenis anggur), serahi (botol parfum), piala, gelas, kendi, vas dan hulu pisau (Pojoh, 2008:54-59).

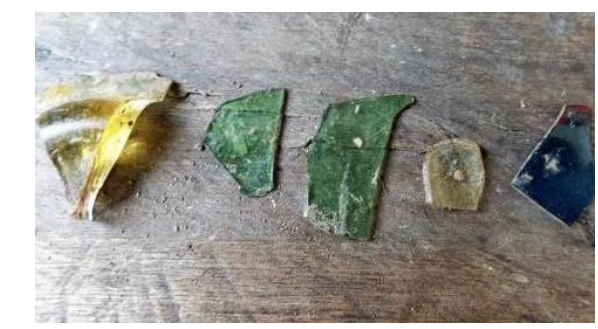

Gambar 5. Fragmen-fragmen benda kaca di Situs Kanal 12

(Sumber: dok. Balar Sumsel 2016)

Keramik-keramik banyak ditemukan di Situs Kanal 12 dalam kondisi pecah. Selain lokasi tersebut, penduduk juga menemukan keramik-keramik utuh dan artefak-artefak batu, antara lain batu pipisan (grinding stone) dalam penggalian liar di Kampung Pasir, wilayah Desa Ulak Kedondong. Keramik-keramik utuh berbentuk guci dan tempayan dalam berbagai ukuran, bahan batuan (stoneware) yang dilapisi glasir warna hijau kecoklatan yang tidak menutupi seluruh bagian dasar. Jenis keramik ini serupa dengan guci-guci dan tempayan-tempayan yang ditemukan pada barang muatan kapal karam abad ke-10 di perairan Laut Jawa di Cirebon bagian utara. 


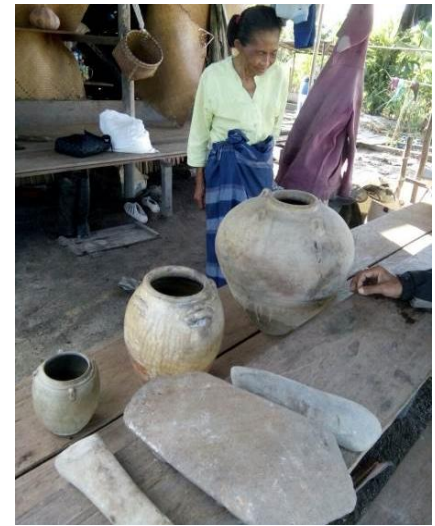

Gambar 6. Batu pipisan dan keramik Cina di Kampung Pasir, Desa Ulak Kedondong (Sumber: dok. N. Rangkuti 2016)

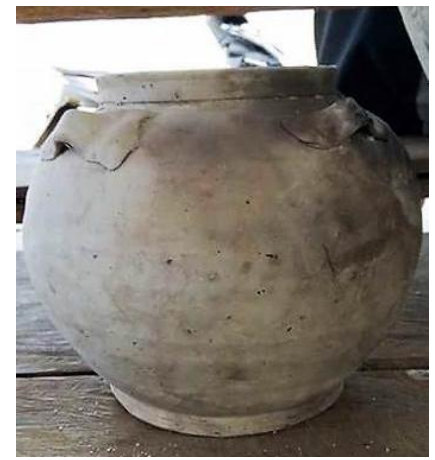

Gambar 7. Guci keramik Cina abad ke 10 di Kampungpasir, Desa Ulak Kedondong

(Sumber: dok. N. Rangkuti 2016)

Manik-manik, mata uang logam (coins) dan cincin-cincin emas yang dihias dengan batu mulia banyak ditemukan oleh para penggali liar di Kanal 12 dan Bukit Tengkorak. Manik-manik terbuat dari bahan batu dan kaca. Manik-manik dari batu kornelian diperkirakan berasal dari India. Salah satu jenis manik-manik yang ditemukan, terdapat manik-manik kaca berupa manik-manik mata (eye beads). Jenis manik-manik ini ditemukan pula pada muatan barang kapal karam abad ke 10 di perairan Cirebon. Bentuknya bulat (spherical) dengan diameter 1,0-2,0 cm. Menurut Ingrid HE Pojoh (2008:62) sebaran terbanyak manik-manik jenis ini adalah di Asia dan Mesir, dan belakangan lebih populer di negara-negara Islam Asia Barat.

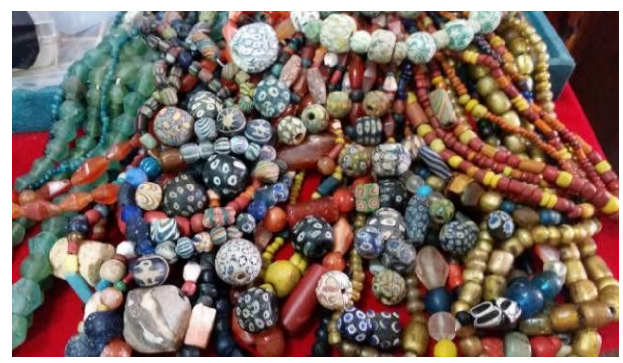

Gambar 8. Manik-manik batu, kaca dan emas dari Situs Kanal 12 dan Bukit Tengkorak

(Sumber: dok. Penduduk Desa Ulak Kedondong 2015)

\section{DISKUSI DAN PEMBAHASAN}

\section{Posisi Teluk Cengal dalam Jaringan Maritim}

Teluk Cengal yang berada di ujung timur Selat Bangka merupakan teluk yang ideal untuk menjadi lokasi bandar pelabuhan karena terletak di persimpangan jalur pelayaran antara Selat Bangka dengan Selat Sunda dan Laut Jawa di selatan. Di bagian timur laut Selat Bangka terdapat Selat Lepar (di antara Pulau Bangka dan Pulau Lepar) dan Selat Gaspar (antara Pulau Bangka dan Pulau Belitung) dan Selat Karimata (antara Pulau Belitung dan Pulau Kalimantan).

Keterangan mengenai jalur pelayaran di sekitar Selat Bangka diperoleh dari catatan-catatan Portugis abad ke-16 -17. PY. Manguin (1984:17-24) berpendapat bahwa catatan-catatan dari para pelaut Portugis, yaitu roteiros (bukubuku pemandu laut) mengenai lautan Indonesia, terutama jalur pelayaran Selat Bangka dapat memberikan petunjuk mengenai keadaan Selat Bangka dan pantai tenggara Sumatra yang tidak jauh berbeda dengan kondisi sekarang. Jalur yang dilalui para pemandu 
Portugis adalah sepanjang pantai Sumatra yang berlumpur untuk menghindari karang-karang di sepanjang pantai Bangka (Manguin, 1984:18).
Lucipara . yang di tempatkan di timur sebuah teluk yang berlumpur. Pada teluk itu digambarkan sebuah saluran yang disebut Canal de Lucipara. Tidak diketahui apakah

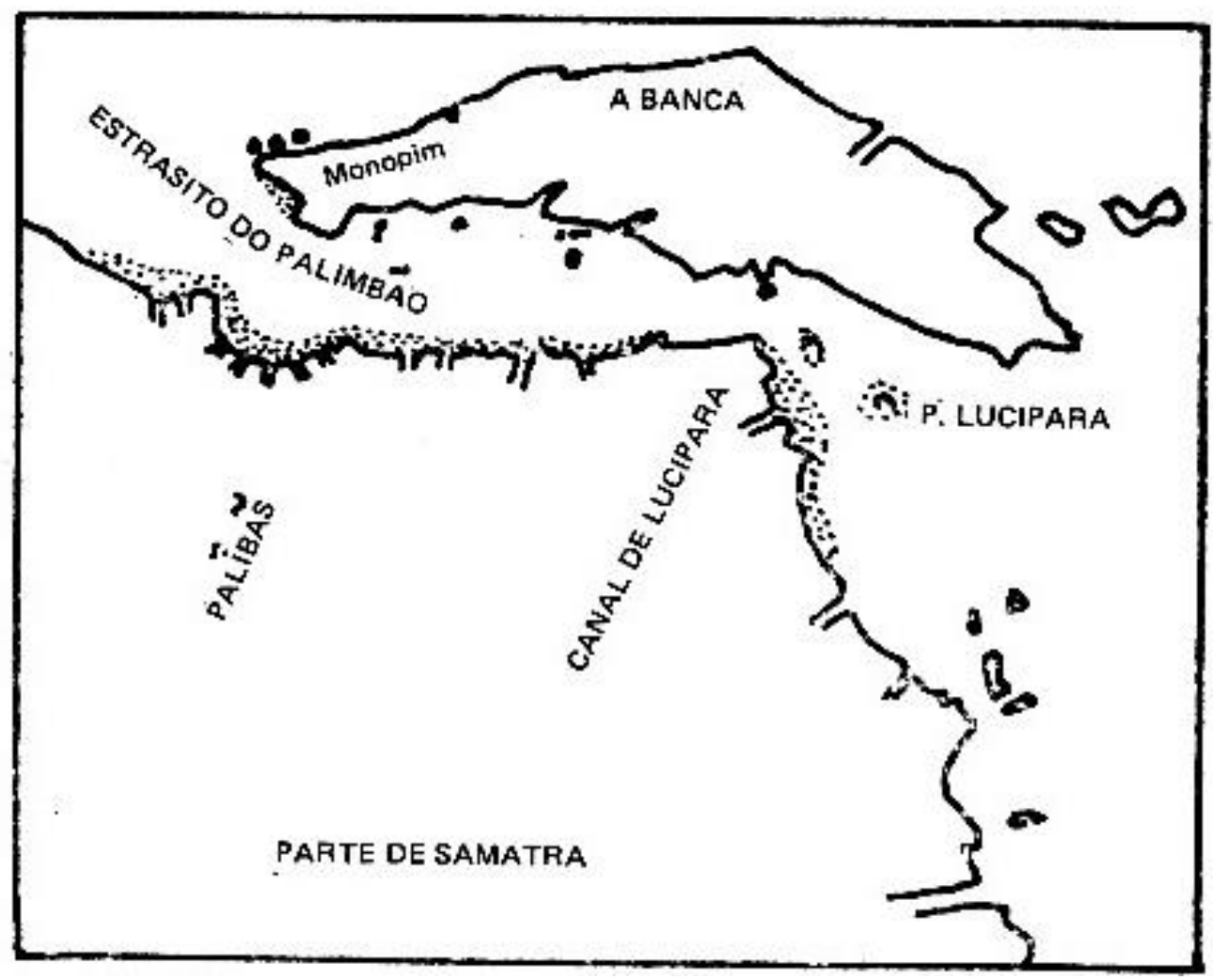

Gambar 9. Peta sketsa Selat Bangka berdasarkan Andre Persira Dos Reis tahun 1654

(Sumber: dok. Manguin 1984)

Roteiros dilengkapi juga dengan peta-peta. Peta-peta yang dibuat Francisco Rodrigues tahun 1513 dan Andre Persira Dos Reis tahun 1654 menunjukkan pantai Sumatra tidak mengalami perubahan garis pantai yang berarti. Palembang terletak agak ke hulu tidak di dekat pantai. Kedua peta itu juga menggambarkan adanya Pulau Maspari yang disebut dalam peta 1513 yaitu Nucapara, letaknya di timur laut pantai Sumatra. Pada peta tahun 1654 Pulau Maspari disebut saluran itu saluran buatan atau sungai alam. Sebagaimana diketahui di Teluk Cengal bermuara Sungai Riding, Sungai Lebung Hitam, Sungai Lumpur, Sungai Jeruju dan Sungai Pasir. Apakah Canal de Lucipara yang dimaksud adalah Sungai Lumpur? Sungai tersebut merupakan sungai yang lebar dan menjadi lalu lintas perahu dan kapal dari Selat Bangka ke pedalaman teluk dan sebaliknya. yang sampai sekarang menjadi sungai yang ramai lalu lintasnya dari dan ke laut dan pedalaman dengan perahu bermotor.

Roteiros juga memberi informasi mengenai kondisi perairan di pantai tenggara Sumatra. Kapal- 
kapal Portugis menyusuri sepanjang garis pantai Sumatra yang berlumpur dan dangkal. Para pelaut lebih memilih terperosok ke dalam lumpur di Sumatra daripada menabrak karang di sekitar Pulau Bangka (Tanudirdjo, 2008:14-15). Tome Pires (1512-1515), seorang pengelana bangsa Portugis, dalam perjalanan ke Selat Malaka menyebut Pulau Lucipara yang terletak di bagian akhir Selat Bangka. Dalam catatan perjalanannya itu ia menjelaskan bahwa Pulau Lucipara merupakan titik penanda untuk kapal-kapal yang berlayar menuju Kerajaan Sunda, Pelabuhan Jepara, dan Kepulauan Malaka (Cortessao 1944:157; Novita 2015:68).

Informasi yang ditulis oleh $\mathrm{J}$. Stanton, seorang nakhoda Eropa pada abad ke-19 menggambarkan kondisi perairan di sekitar Pulau Lucipara di ujung timur Selat Bangka. Pulau Maspari atau Lucipara yang berhadapan dengan Tanjung Kait di Teluk Cengal membelah laut Selat Bangka menjadi dua terusan (channe), yaitu Terusan Lucipara (Lucipara Channel) dan Terusan Stanton (Stanton Channel). Kapal-kapal yang melalui Terusan Lucipara menyusuri garis pantai Sumatra yang dangkal dan berlumpur. Terusan Stanton yang dekat dengan Pulau Bangka merupakan terusan yang lebih dalam, berkarang dan arusnya deras (Stanton, 1860:71-100).

Gambaran mengenai kondisi perairan Selat Bangka dan sekitar Pulau Lucipara memberi petunjuk bahwa pada masa lalu kapal-kapal yang melalui jalur Selat Bangka menuju Selat Sunda dan Laut Jawa atau sebaliknya, lebih sering menyusuri garis pantai Teluk Cengal daripada garis pantai Pulau Bangka. Teluk yang terlindung itu merupakan lokasi yang sering digunakan sebagai lokasi bandar pelabuhan. Data arkeologi yan ditemukan di Teluk Cengal memberikan gambaran mengenai adanya pusat permukiman di Daerah Aliran Sungai Lumpur dan adanya aktivitasaktivitas kemaritiman dengan ditemukannya perahu-perahu dan artefak-artefak impor dari Cina, India dan Persia. Pusat permukiman di lokasi tersebut diperkirakan sebagai kawasan bandar pelabuhan masa Sriwijaya yang diperkirakan dari abad ke 8 - 10 Masehi. Pada abad ke-8 sampai abad ke-13, Sriwijaya berkembang menjadi maharaja penguasa laut (thalassocracy) di Asia Tenggara meliputi wilayah Kambujadesa (sampai abad ke-10), Semenanjung Melayu, pantai timur Sumatra dan Jawa bagian barat (Wheatley:2010:292-300). Pada periode itu terdapat sejumlah bandar pelabuhan di Semenanjung Melayu, antara lain Grahi, Tambralingga, Langkasuka, Pahang dan Kedah. Bandar pelabuhan di pantai timur Sumatera terdapat di Lamuri (Aceh), Pane, Kampar dan Palembang. Di Jawa bagian barat Sriwijaya menguasai wilayah Sunda.

Terkait dengan wilayah Sunda, Prasasti Kota Kapur bertarikh 28 April 682 yang ditemukan di Situs Kota Kapur di Pulau Bangka menceritakan tentang bala tentara Sriwijaya akan menyerang Bhumi Jawa. Penelitian mutakhir menguatkan bukti bahwa lokasi Bhumi Jawa terdapat di kawasan Situs Batujaya, bagian dari Kerajaan Tarumanegara yang terletak di pesisir utara Jawa di Kabupaten Krawang, Jawa Barat (Djafar: 2010:108-109). Hal ini menunjukkan bahwa pada akhir abad ke-7 atau awal abad ke-8 bandar pelabuhan di pesisir utara Jawa Barat telah menjadi wilayah maharaja laut 
Sriwijaya. Hal yang menarik untuk dibayangkan mengenai jalur laut yang dilayari oleh perahu-perahu yang membawa bala tentara Sriwijaya dari Kota Kapur menuju Batujaya. Besar kemungkinan perahu-perahu itu berangkat dari dermaga Kota Kapur di tepi Sungai Mendo (Menduk) menuju muara sungai di Selat Bangka. Perahuperahu Sriwijaya selanjutnya menyusuri garis pantai Sumatra yang memiliki banyak ceruk dan tanjung. Tanjung yang pertama dilalui adalah Tanjung Selokan, Tanjung Tapah, Tanjung Koyan, Tanjung Jatigombol, Tanjung Kait (lihat Gambar 1) dan sampai di Teluk Cengal, yang berarti telah memasuki laut Jawa. Dari Teluk Cengal kemudian kapal menyusuri pantai utara Jawa menuju Batujaya di pesisir utara Krawang.

Jalur pelayaran melalui Selat Bangka ke Laut Jawa yang dilakukan kapal-kapal Sriwijaya pada abad ke-7 tersebut berlanjut pada abad-abad berikutnya. Bukti-bukti arkeologis berupa kapal karam bersama barang muatannya di perairan Cirebon memberi penanda bahwa pada abad ke-10 kapal-kapal niaga Sriwijaya mengadakan perdagangan niaga di bandarbandar pelabuhan antara yang terdapat di pantai utara Jawa. Kapal kayu tradisi Asia Tenggara itu ditemukan pada tahun 2004 di perairan Cirebon pada kedalaman 30 meter. Kapal sarat dengan barang muatan asal Cina, India, Timur Tengah dan juga Sriwijaya.

Terkait dengan rekonstruksi jalur pelayaran kapal yang tenggelam di Laut Jawa tersebut, Bambang Budi Utomo (2008) menafsirkannya berdasarkan asal muasal jenis barang muatan kapal. Lebih lanjut Utomo menyatakan:
"Kapal-kapal dengan muatan keramik-keramik Tiongkok diduga berasal dari pelabuhan Kanton dengan destinasi pelabuhan Sriwijaya. Kapal-kapal dengan muatannya barang-barang kaca diduga berasal dari kawasan Timur Tengah dengan pelabuhan asalnya di sekitar Teluk Persia seperti Basra dan Kufah, dan pelabuhan destinasinya Sriwijaya. Dari Sriwijaya barang-barang komoditi dari berbagai pelabuhan tersebut kemudian dikapalkan lagi dengan menggunakan kapal Sriwijaya (kapal yang dibuat dengan teknologi Asia Tenggara) untuk dibawa ke pelabuhan-pelabuhan di Jawa" (Utomo:2008:109).

Pendapat Utomo perlu ditelusuri lebih jauh. Dimanakah lokasi pelabuhan Sriwijaya yang dimaksud? Apakah lokasi pelabuhan berada di Palembang atau lokasinya di daerah pantai tenggara Sumatra yang berada di sepanjang Selat Bangka? Bandar pelabuhan di Teluk Cengal dapat diajukan sebagai kemungkinan pernah menjadi lokasi pengapalan lagi barang-barang dari luar, mengingat posisinya yang strategis pada persimpangan jalur niaga maritim Selat Bangka, Selat Sunda dan Laut Jawa.

\section{KESIMPULAN}

Kajian ini memberikan gambaran mengenai ramainya lalu lintas pelayaran yang melintasi garis pantai Teluk Cengal sejak masa Sriwijaya. Di teluk tersebut ditemukan kawasan permukiman kuna yang luas dan padat di Daerah Aliran Sungai Lumpur sampai ke aliran Sungai Jeruju. Kawasan permukiman itu memiliki pelabuhan sungai yang kemudian berkembang menjadi salah satu pelabuhan antara 
(entreport) Sriwijaya sejak abad ke-8 sampai abad ke-10, periode dimana Kerajaan Sriwijaya menjadi penguasa atau maharaja maritim (thalassocracy) di Asia Tenggara. Teluk Cengal memiliki posisi yang strategis, yaitu di persimpangan jalur maritim di antara Selat Bangka, Selat Sunda dan Laut Jawa. Kapalkapal yang menyusuri Teluk Cengal baik dari Asia dan Semenanjung Melayu dari barat daya maupun kapal-kapal dari Jawa dan wilayah timur nusantara, kemungkinan ada yang singgah di pelabuhan Teluk Cengal. Kapal-kapal singgah menunggu angin musim untuk kembali ke tempat asalnya. Para saudagar, nahkoda dan para pelaut dari luar tinggal sementara di kawasan pelabuhan setelah bongkar muat barang dari kapal dan melakukan transaksi komoditi dengan masyarakat setempat. Komoditi lokal yang diminati antara lain getah damar yang banyak ditemukan di sekitar Teluk Cengal, yaitu pada situs-situs arkeologi di Air Sugihan.

Kawasan Teluk Cengal yang berfungsi sebagai pelabuhan antara (entreport) pada masa Sriwijaya bersifat hipotesis. Oleh karena itu perlu diuji melalui serangkaian penelitian untuk mencari sisa-sisa dermaga kayu, tonggak-tonggak kayu penambat perahu dan perahuperahu di kawasan situs di antara Sungai Ketupak-Sungai Langipi di daerah aliran Sungai Lumpur. 


\section{DAFTAR PUSTAKA}

Abbas, Novida. 2013 "Perahu Kuna Punjulharjo: Sebuah Hasil Penelitian”. Dalam Perahu Nusantara, 55-73. ed. Inajati Adrisijanti. Yogyakarta: Balai Arkeologi.

Cortesao, Armando. 1944. The Suma Oriental of Tome Pires: An Account of The East. London: Hakluyt Society.

Djafar, Hasan. 2010. Kompleks Percandian Batujaya Rekonstruksi Sejarah Kebudayaan Daerah Pantai Utara Jawa Barat. Bandung: Kiblat Buku Utama, Ecole francaise d'Exteme-Orient Pusat Penelitian dan Pengembangan Arkeologi Nasional KITLV-Jakarta.

Koestoro, Lucas Partanda. 1993 "Tinggalan Perahu di Sumatera Selatan: Perahu Sriwijaya?" Dalam Sriwijaya Dalam Perspektif Arkeologi dan Sejarah C1-1-C1-10. Palembang: Pemerintah Provinsi Sumatera Selatan.

Mangga, S. Andi, Sukardi dan Sidarto. 1993. Peta Geologi Lembar Tulung Selapan. Bandung: Pusat Penelitian dan Pengembangan Geologi.

Manguin. PY, "Garis Pantai Sumatera Di Selat Bangka: Sebuah Bukti Baru Tentang Keadaan Yang Permanen Pada Masa Sejarah". Amerta Berkala Arkeologi No.8 1984: 17-24.

Novita, Aryandini. "Perairan Utara Belitung Dalam Lintas Pelayaran Masa Lalu". Siddhayatra Jurnal Arkeologi 2015: 57-72.

Pojoh, Ingrid HE. 2008 "Bab 3. Muatan Kapal (Kaca dan Manik-Manik)". Dalam Kapal Karam Abad ke-10 di Laut Jawa Utara Cirebon 54-59. ed. Bambang Budi Utomo. Jakarta: PANNAS BMKT.

Rangkuti, Nurhadi. 2007. “Jejak Bahari Kota Kapur”. Harian Kompas tanggal 5 November 2007.

Rangkuti, Nurhadi. (2016, Maret 21). Terbakarnya Wanua Sriwijaya di Lahan Gambut Sumatera Selatan Dalam http://mongabay.co.id.

Rangkuti, Nurhadi dan Budi Wiyana. 2016. "Hasil-Hasil Penelitian Arkeologi di Lahan Gambut Provinsi Sumatera Selatan”. Palembang: Balai Arkeologi (tidak diterbitkan).

Reid, Anthony, 2015. Asia Tenggara Dalam Kurun Niaga 1450-1680. Jilid 2: Jaringan Perdagangan Global. Jakarta: Yayasan Pustaka Obor Indonesia.

Stanton, J, "The Survey of Banka Strait." Dalam The Nautical Magazine And Nabal Chronical for 1860. A Journal of Papers of Subjects Caonnected with Maritime Affair, 1860: 71-133. 
Tanudirdjo , Daud Aris, 2008 "Bab I. Pendahuluan: Awal Jaringan Pelayaran dan Perdagangan" Dalam Kapal Karam Abad ke-10 di Laut Jawa Utara Cirebon, ed. Bambang Budi Utomo. Jakarta: PANNAS BMKT, hal 1-26.

Utomo, Bambang Budi. 2008 "Bab V. Wilayah Asal Kapal dan Tempat-Tempat Persing-gahan" Dalam Kapal Karam Abad ke-10 di Laut Jawa Utara Cirebon 91-109, ed. Bambang Budi Utomo. Jakarta: PANNAS BMKT.

Utomo, Bambang Budi. 2015 "Kota Kapur: Pelabuhan Sungai di Tepi Selat" Dalam Kehidupan Purba di Lahan Gambut, 111-127, ed. Bambang Budi Utomo. Surakarta: PT Aksarra Sinergi Media.

Wheatley, Paul. 2010 The Golden Khersonese. Kuala Lumpur: University of Malaya Press.

Wiyana, Budi. 2013 "Temuan Perahu kuno di Sumatera Bagian Selatan" Dalam Perahu Nusantara, 149 - 164 ed. Inajati Adrisijanti. Yogyakarta: Kepel.

Wiyana, Budi, Yustinus Suranto, Harry Octavianus Sofian, Wahyu Rizqi Adhifani. 2015 Laporan Hasil Penelitian Arkeologi: Kronologi Situs di Kawasan Tulung Selapan Kabupaten Ogan Komering Ilir, Provinsi Sumatera Selatan. Palembang: Balai Arkeologi (tidak diterbitkan). 